\title{
Urbanization and development of vertical agriculture in Russia
}

\author{
Galina Kurcheeva ${ }^{1}$, George Klochkov, ${ }^{2, *}$ and Anna Aletdinova ${ }^{1}$ \\ ${ }^{1}$ Novosibirsk State Technical University, ERP Systems Department, 630073 Novosibirsk, Russia \\ ${ }^{2}$ Novosibirsk State University of Economics and Management, Department of Applied Informatics, \\ 630099, Novosibirsk, Russia
}

\begin{abstract}
This paper discusses new technologies for the production of high-quality agricultural products, which are environmentally friendly and the production of which is now associating not only to rural areas. According to the authors, the concept of a digital city is now widening; it includes new trends, when agricultural production extends its boundaries, including vertical agriculture and farming urbanization.
\end{abstract}

\section{Introduction}

The agricultural sector of Russia is characterized by new trends, these are the digitalization of socio-economic activity and the urbanization of agriculture, when, in the context of a decrease in the rural population, part of production is transferred to cities.

Improving the quality of life of the population is one of the key tasks of the socioeconomic development of Russia. To solve this problem, projects such as "smart city/ settlement" or "digital city/ settlement" are being developed and implemented, including such areas as "smart medicine", "smart transport", "smart ecology", "smart environment", "urban agriculture "and others [1, 2].

The number of inhabitants of a settlement for assigning it the status of a city is conditional and depends on many factors. Usually, in Russia, settlements with a population of more than 10-12 thousand inhabitants receive the status of a city. However, there are cities with less than 10 and even less than 5 thousand people. At the same time, there are many urban-type settlements and even rural settlements with more than 10 thousand inhabitants.

The objective of this study is to determine the distinctive features of vertical and urban agriculture, in order to assess the trends in the implementation of projects in the federal districts of the country, to compare the factors that positively and negatively affect the urbanization of agriculture.

\footnotetext{
* Corresponding author: klgeorge@yandex.ru
} 


\section{Related work and methods}

\subsection{Related work}

Most of the population of Russia is urban dwellers. We note the high proportion of urbanization in the country, which is growing every year. According to our estimates, by 2030 the rural population will reach 23 million people, that is, it will decrease by 4 million people in 20 years (Fig. 1).

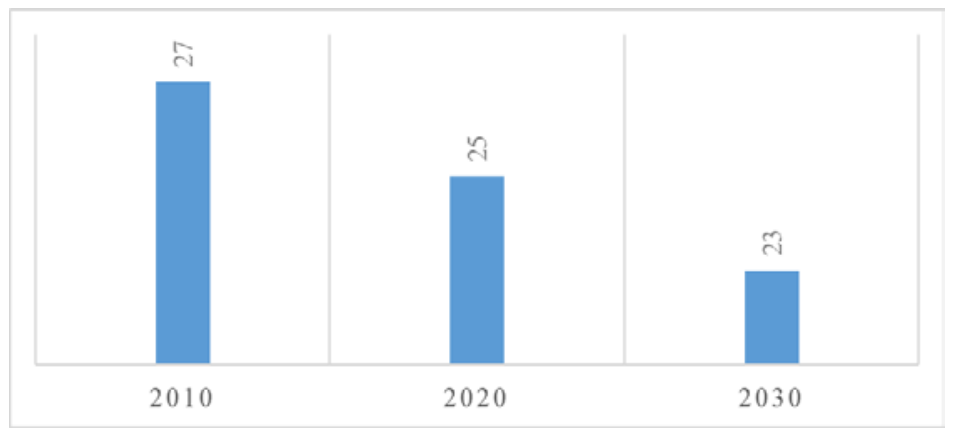

Fig. 1. Decrease in the share of the rural population of Russia according to the UNICEF forecast, \% (calculated by the authors based on the data [3])

In the scientific literature, there is a wide discussion of the terminology associated with the concept of urbanization of the agricultural sector (Table 1). There are different interpretations of the concept of urbanization; some researchers consider it as a method, others as a process.

Table 1. Approaches to the interpretation of the concept of urbanization.

\begin{tabular}{|c|c|c|c|}
\hline No. & Interpretation & Authors & $\begin{array}{l}\text { Feature } \\
\text { of the } \\
\text { Interpret } \\
\text { ation }\end{array}$ \\
\hline 1 & $\begin{array}{l}\text { A new way of populating territories, taking into account a } \\
\text { complex of interrelated conditions for comfortable, } \\
\text { environmentally friendly and economically self-sufficient } \\
\text { living of the population in settlements of a new type }\end{array}$ & $\begin{array}{l}\text { O. Gorb, I. Yasnolob, D. } \\
\text { Alla, Y. Kaliuzhna [4] }\end{array}$ & Method \\
\hline 2 & $\begin{array}{l}\text { Increasing the importance of cities for society. The growth of } \\
\text { cities, especially those with more than one million people, an } \\
\text { increase in the number of urban population in the country, } \\
\text { region, world }\end{array}$ & $\begin{array}{l}\text { A. Caragliu, C. F. Del } \\
\text { Bo [5] }\end{array}$ & \multirow[t]{4}{*}{ Process } \\
\hline 3 & $\begin{array}{l}\text { A process in which the city plays the main role in the } \\
\text { development of society, and an important feature is the inherent } \\
\text { relationship between the population and the city, covering the } \\
\text { social, professional and demographic structure of society, its } \\
\text { way of life, cultural characteristics and the location of } \\
\text { productive forces }\end{array}$ & $\begin{array}{l}\text { Ahmed, Z., Zafar, M. } \\
\text { W., \& Ali, S. [6] }\end{array}$ & \\
\hline 4 & $\begin{array}{l}\text { Urban growth, an increase in the proportion of urban } \\
\text { population in the country, region, and the world. } \\
\text { Multilevel demographic, socio-economic and geographic } \\
\text { process based on historically established forms of society and } \\
\text { territorial division of labor }\end{array}$ & $\begin{array}{c}\text { R. Camagni, R. Capello, } \\
\text { A. Caragliu [7] }\end{array}$ & \\
\hline 5 & $\begin{array}{l}\text { A complex socio-economic phenomenon, which means a set of } \\
\text { processes associated with the spread of urban lifestyles and } \\
\text { with changes in the settlement system. }\end{array}$ & $\begin{array}{l}\text { B. Surya, H. Hadijah, S. } \\
\text { Suriani, B. Baharuddin, } \\
\text { A. T. Fitriyah, F. Menne, } \\
\text { E. S. Rasyidi [8] }\end{array}$ & \\
\hline
\end{tabular}


The term urbanization is applied not only to territories, but also to areas of economic activity, industries and sectors of the economy, for example, to the agricultural sector, justifying its development as a high-tech cluster, on the one hand, and on the other, separating the link between the concepts of "agricultural production" and "rural territory ". A. Kumar, J. S. Rattan, when describing an ecologically clean city, write about the need to create various agricultural structures, plots within its boundaries, about vertical agricultural buildings of the "agro-tower" type, which will reduce the time of delivery of food to consumers [9].

Thanks to new architectural and engineering solutions, information and communication technologies that ensure the automation of the agro-industrial complex, a number of developed countries are already designing and implementing vertical agriculture. $\mathrm{K}$. Jürkenbeck, A. Heumann, A. Spiller, analysing the concepts and technologies of vertical agriculture and sustainable agriculture, do not find a significant difference in them [10].

Let us highlight the features of urbanization of the agricultural sector:

- possible lack of binding to the ground;

- distribution on the territory of cities;

- minimization of the used area, but maximization of the used volume of farms;

- creation of digital ecosystems for the management of vertical farms;

- using new architectural and engineering solutions, information and communication technologies, methods and technologies of selection for the production of agricultural sector products.

According to the authors, urbanization of the agricultural sector is the process of spreading high-tech industries of the agricultural sector in the territory of cities.

Thus, by the sixth technological order, more and more urban dwellers will be involved in the agricultural sector, and there will be a need for specialists mastering in new technologies. However, already now, new solutions are required from the agricultural sector, which only human capital and new technologies could implement. As L. Palmer writes, in the United States there is a post-industrial trend of the emergence of an urban rural population [11].

We can assume that there is a tendency to blur the differences between the rural and the urban population, agricultural and other sectors of production activity, but so far, according to the research of V.A. Ilyin, T.V. Uskova, Russia is far from this trend [12, 13]. Nevertheless, at the same time, to develop technological solutions for the implementation of scenarios for the scientific and technological development of agriculture, specialists from various industries are already involved.

\subsection{Methods}

The study refers to assessment the quality of life of the population concerning the possibilities of obtaining environmentally friendly products in the territory of "smart settlements".

One of the areas of "smart agriculture" is the urbanization of agriculture. Let us highlight the factors influencing the formation of "smart agriculture". For this purpose, it is necessary to consider the terminology associated with the development of urban agriculture and the characteristics of urbanization. Then you need to collect and process data regarding the ratio of the share of rural and urban population in the Federal Districts of Russia, and get prognostic estimates until 2030

Information on the presence and distribution of vertical farms, as examples of urbanization in the Federal Districts, we will collect from online Internet resources. 


\section{Results and discussion}

To determine the differences between vertical and urban agriculture, we considered such characteristics as the goal, main tasks, territorial location, and characteristics of the premises used (Table 2). The analysis showed that from the standpoint of improving the quality of life, the most attractive features are the creation of an eco-friendly city and the minimization of used land areas.

Table 2. Characteristic Features of Vertical and Urban Agriculture.

\begin{tabular}{|c|c|c|c|}
\hline No. & Characteristic & Vertical Agriculture & Urban Agriculture \\
\hline 1 & Concept & $\begin{array}{l}\text { The concept of agriculture } \\
\text { aimed at providing the } \\
\text { population with food, and } \\
\text { some of the industry with raw } \\
\text { materials, using new } \\
\text { technological and architectural } \\
\text { solutions based on vertical } \\
\text { surfaces }\end{array}$ & $\begin{array}{l}\text { The concept of agriculture } \\
\text { aimed at providing the } \\
\text { population with food, and } \\
\text { some industries with raw } \\
\text { materials, implemented in } \\
\text { cities and megalopolises }\end{array}$ \\
\hline 2 & Main goal & \multicolumn{2}{|c|}{ Food supply of the population } \\
\hline 3 & Main tasks & $\begin{array}{l}\text { Ensure the production of } \\
\text { agricultural products and raw } \\
\text { materials while minimizing the } \\
\text { binding to land plots }\end{array}$ & $\begin{array}{l}\text { Provide the population of } \\
\text { cities with the production of } \\
\text { fresh food and the industry } \\
\text { with agricultural raw } \\
\text { materials. } \\
\text { Create an eco-friendly city }\end{array}$ \\
\hline 4 & Territorial location & Any location & Cities, megalopolises \\
\hline 5 & Use of premises & $\begin{array}{c}\text { Many-storied premises } \\
\text { Minimization of the used land } \\
\text { area }\end{array}$ & $\begin{array}{l}\text { The use of any city premises } \\
\text { including warehouses, old } \\
\text { factories, etc. } \\
\text { Making greenhouses in } \\
\text { residential premises }\end{array}$ \\
\hline
\end{tabular}

The urbanization of Russian regions is heterogeneous (Table 3). At the same time, due to natural and economic, socio-economic and cultural characteristics, there is an unequal development of vertical agriculture. Tsentralny, Northwestern, Volga, Siberian and FarEastern districts specialize in automated vertical farms for the production of vegetables and greens, whereas Uralsky district prefers growing strawberries. There are no vertical farms in the Yuzhny and North-Caucasian districts.

The analysis shows that the highest proportion of the rural population is in the Yuzhny and North Caucasian Federal Districts and in the same districts, automated vertical crop farms are not developing or introducing; however, automated livestock farms are designed (Table 3). This difference is primarily due to the formation of demand, which is fully satisfied in some regions and partially in others.

The structure of costs and, first, the price of electricity (Table 4) have an impact on the promotion of projects of vertical and urban agriculture in the cities of Russia. 
Table 3. Assessment of the federal districts of Russia by the share of the rural population and urbanization of agriculture (2021) (calculated by the authors).

\begin{tabular}{|l|l|l|c|l|l|}
\hline Federal District & $\begin{array}{c}\text { Urban } \\
\text { population } \\
\text { total, } \\
\text { thousand } \\
\text { people }\end{array}$ & $\begin{array}{c}\text { Rural } \\
\text { population } \\
\text { total, } \\
\text { thousand } \\
\text { people }\end{array}$ & $\begin{array}{c}\text { Share of rural } \\
\text { population, \% }\end{array}$ & \multicolumn{2}{|l|}{ Automated vertical farms } \\
\hline Tsentralny & 32400,4 & 6941,8 & 21,4 & available & $\begin{array}{l}\text { Vegetables, } \\
\text { greens }\end{array}$ \\
\hline Northwestern & 11848,2 & 2093,8 & 17,7 & available & $\begin{array}{l}\text { Vegetables, } \\
\text { greens }\end{array}$ \\
\hline Yuzhny & 10378,2 & 6104,2 & 58,8 & none & - \\
\hline North-Caucasian & 5026,9 & 4940,4 & 98,3 & none & - \\
\hline Volga & 21016,8 & 8054,0 & 38,3 & available & $\begin{array}{l}\text { Vegetables, } \\
\text { greens }\end{array}$ \\
\hline Uralsky & 10075,8 & 2253,7 & 22,4 & available & Strawberries \\
\hline Siberian & 12634,5 & 4369,4 & 34,6 & available & $\begin{array}{l}\text { Vegetables, } \\
\text { greens }\end{array}$ \\
\hline Far-Eastern & 5927,1 & 2196,9 & 37,1 & available & $\begin{array}{l}\text { Vegetables, } \\
\text { greens }\end{array}$ \\
\hline Total & 109254,2 & 36916,8 & 33,8 & & \\
\hline
\end{tabular}

Table 4. Indicators affecting the payback of projects "Automated vertical farms".

\begin{tabular}{|l|c|c|c|}
\hline \multicolumn{1}{|c|}{ Regions, cities } & $\begin{array}{c}\text { Electricity price for 1 } \\
\text { kW (rub.) }\end{array}$ & $\begin{array}{c}\text { Total cost share for } \\
\mathbf{a} \mathbf{5 0 0} \mathbf{~ m}^{\mathbf{2}} \text { farm, } \mathbf{~}\end{array}$ & $\begin{array}{c}\text { Payback period } \\
\text { (years) }\end{array}$ \\
\hline Irkutsk region & 2,41 & 9,5 & 3,3 \\
\hline Magadan region & 6,42 & 22 & 4,2 \\
\hline Moscow region & 4,10 & 15 & 3,6 \\
\hline Sakhalin region & $1,53^{*}$ & 6,3 & 3,0 \\
\hline Khanty-Mansiysk & 4,31 & 15,8 & 3,7 \\
\hline $\begin{array}{l}\text { Yamalo-Nenets } \\
\text { Autonomous District }\end{array}$ & 4,10 & 15 & 3,6 \\
\hline Novosibirsk region & 3,37 & 12,8 & 3,5 \\
\hline Chuvashia & 3,46 & 13 & 3,5 \\
\hline Ufa & 4,6 & 16,7 & 3,75 \\
\hline Yaroslavl & 8,6 & 27,3 & 5,0 \\
\hline
\end{tabular}

* The price is valid for the preferential category, which includes vegetable producers

We can compare the payback periods of projects in cities in different districts. It is obvious that even the highest payback period of 5 years meets the requirements of investors, given that demand is growing and supply is limited. Therefore, we can consider the prospects for the development of automated vertical farms as economically justified.

We believe that when developing and implementing new projects, it is necessary to take into account the factors that positively and negatively affect the formation of an "urbanized agricultural sector” as a direction for the development of a "smart city” (Table 5). 
Table 5. Factors Influencing the Formation of the "Urbanized Agricultural Sector" Trend (developed by the authors)

\begin{tabular}{|c|c|c|}
\hline Group of Factors & $\begin{array}{c}\text { Negatively Influencing } \\
\text { Factors }\end{array}$ & $\begin{array}{c}\text { Factors contributing to } \\
\text { development }\end{array}$ \\
\hline $\begin{array}{c}\text { Socio-psychological, } \\
\text { cultural }\end{array}$ & $\begin{array}{c}\text { Conservatism and "internal" } \\
\text { resistance to changes (with } \\
\text { remote access) }\end{array}$ & Choice, assortment growth \\
\hline Economic, technological & $\begin{array}{c}\text { Lack of funds to finance } \\
\text { projects }\end{array}$ & $\begin{array}{c}\text { Availability of modern } \\
\text { technologies, robotization of } \\
\text { processes }\end{array}$ \\
\hline Informational and technological & $\begin{array}{c}\text { Information limitation } \\
\text { associated with inaccurate } \\
\text { information about the quality } \\
\text { and usefulness of products }\end{array}$ & $\begin{array}{c}\text { Website development, remote } \\
\text { delivery, information update }\end{array}$ \\
\hline Organizational and managerial & $\begin{array}{c}\text { Uneven distribution across the } \\
\text { country and cities }\end{array}$ & $\begin{array}{c}\text { Development of communities } \\
\text { in the Internet space, taking } \\
\text { part in the development of } \\
\text { "smart agriculture" }\end{array}$ \\
\hline Political and legal & $\begin{array}{c}\text { Limitations associated with } \\
\text { international sanctions }\end{array}$ & State support, benefits \\
\hline
\end{tabular}

\section{Conclusion}

The study refers to assessment the quality of life of the population concerning the possibilities of obtaining environmentally friendly products in the territory of "smart settlements".

One of the areas of "smart agriculture" is the urbanization of agriculture. Let us highlight the factors influencing the formation of "smart agriculture". For this purpose, it is necessary to consider the terminology associated with the development of urban agriculture and the characteristics of urbanization. Then you need to collect and process data regarding the ratio of the share of rural and urban population in the Federal Districts of Russia, and get prognostic estimates until 2030.

Information on the presence and distribution of vertical farms, as examples of urbanization in the Federal Districts, we will collect from online Internet resources.

\section{References}

1. G.I. Kurcheeva, G.A. Klochkov IOP Conf. Ser.: Earth Environ. Sci. 341(1), 012021 (2019)

2. G.I. Kurcheeva and G.A. Klochkov IOP Conf. Ser.: Earth Environ. Sci. 666032040 (2021)

3. An Urban World UNICEF Retrieved 21.01.2021 from https://www.unicef.org/sowc2012/urbanmap/

4. O. Gorb, I. Yasnolob, D. Alla, Y. Kaliuzhna Journal of Environmental Management \& Tourism. 8(3) 19 (2017)

5. A. Caragliu, C. F. Del Bo Technological Forecasting and Social Change 142 (2019)

6. Z. Ahmed, M.W. Zafar, S. Sustainable Cities and Society 55 (2020) 
7. R. Camagni, R. Capello, A. Caragliu Seminal studies in regional and urban economics (Springer, Cham, 2017)

8. B. Surya, H. Hadijah, S. Suriani, B. Baharuddin, A. T. Fitriyah, F. Menne, E. S. Rasyidi Land 9(9) (2020)

9. A. Kumar, J. S. Rattan Smart Cities and Construction Technologies (IntechOpen, 2020)

10. K. Jürkenbeck, A. Heumann, A. Spiller Sustainability 11(15) (2019)

11. Palmer L. Nature Sustainability 1(1) (2018)

12. V.A. Ilyin, T.V. Uskova Federalism, 3 (2012) (In Russian)

13. Where in Russia is it profitable to build vertical farms Retrieved 01.02.2021 from https://ifarmproject.ru/blog/2021/03/gde-vygodno-stroit-vertikalnyu-fermu-1 Russian) 